\title{
A mononuclear cobalt(II) hydroxo complex: synthesis, molecular structure, and reactivity studies
}

\author{
Udai P. Singh $\cdot$ Preeti Babbar $\cdot$ Pooja Tyagi $\cdot$ \\ Thomas Weyhermüller
}

Received: 29 March 2008/Accepted: 28 May 2008/Published online: 18 September 2008

(C) Springer Science+Business Media B.V. 2008

\begin{abstract}
A novel Co(II) hydroxo complex $\mathrm{Co}\{\mathrm{HB}(3-$ $\left.\left.{ }^{\mathrm{t}} \mathrm{Bu}-5-{ }^{\mathrm{i}} \mathrm{Prpz}\right)_{3}\right\}(\mathrm{OH}) 4$ \{where $\mathrm{HB}\left(3-{ }^{\mathrm{t}} \mathrm{Bu}-5{ }^{\mathrm{i}}{ }^{\mathrm{Prpz}}\right)_{3}=$ hydrotris(3-tert-butyl-5-isopropylpyrazol-1-yl)borate\} has been prepared and its molecular structure has been determined by $\mathrm{X}$-ray crystallography. This complex is mononuclear with distorted tetrahedral geometry. The reaction of $\mathrm{CO}_{2}$ with $\mathrm{Co}\left\{\mathrm{HB}\left(3-{ }^{\mathrm{t}} \mathrm{Bu}-5-{ }^{\mathrm{i}} \mathrm{Prpz}\right)_{3}\right\}(\mathrm{OH})$ resulted in the formation of a $\mu$-carbonato bridged binuclear complex $\left[\mathrm{Co}\left\{\mathrm{HB}\left(3-^{\mathrm{t}} \mathrm{Bu}-\right.\right.\right.$ 5 - $\left.\left.\left.{ }^{\mathrm{P}} \mathrm{Prpz}\right)_{3}\right\}\right]_{2}\left(\mathrm{CO}_{3}\right)$ wherein the carbonate group is bound to both metal centers in an asymmetrical manner. In order to explore the role of labile metal complexes in promoting ester hydrolysis, complexes $\left[\mathrm{Co}\left\{\mathrm{HB}\left(3,5-{ }^{\mathrm{i}} \mathrm{Pr}_{2} \mathrm{pz}\right)_{3}\right\}\right]_{2}(\mathrm{OH})_{2}$ and $\mathrm{Co}\left\{\mathrm{HB}\left(3-{ }^{\mathrm{t}} \mathrm{Bu}-5-{ }^{\mathrm{i}} \mathrm{Prpz}\right)_{3}\right\}(\mathrm{OH})$ have been used as catalysts in the hydrolysis of both carboxylate as well as phosphate esters. The product of 4-nitrophenylacetate hydrolysis with $\mathrm{Co}\left\{\mathrm{HB}\left(3-{ }^{\mathrm{t}} \mathrm{Bu}-5-{ }^{\mathrm{i}} \mathrm{Prpz}\right)_{3}\right\}(\mathrm{OH})$ was isolated as four coordinate $\mathrm{Co}\left\{\mathrm{HB}\left(3-{ }^{t} \mathrm{Bu}-5-{ }^{\mathrm{i}} \mathrm{Prpz}\right)_{3}\right\}\left(\mathrm{OC}_{6} \mathrm{H}_{4}-4-\mathrm{NO}_{2}\right) \quad$ 6, whereas the reaction of 4-nitrophenyltrifluoroacetate with $\left[\mathrm{Co}\left\{\mathrm{HB}\left(3,5-{ }^{\mathrm{i}} \mathrm{Pr}_{2} \mathrm{pz}\right)_{3}\right\}\right]_{2}(\mathrm{OH})_{2}$ resulted the formation of the six coordinate $\mathrm{Co}\left\{\mathrm{HB}\left(3,5-{ }^{\mathrm{i}} \mathrm{Pr}_{2} \mathrm{pz}\right)_{3}\right\}\left(\mathrm{OC}_{6} \mathrm{H}_{4}-4-\mathrm{NO}_{2}\right)(\mathrm{MeCN})_{2}$ species.
\end{abstract}

Electronic supplementary material The online version of this article (doi:10.1007/s11243-008-9143-2) contains supplementary material, which is available to authorized users.

U. P. Singh $(\bowtie) \cdot$ P. Babbar $\cdot$ P. Tyagi

Department of Chemistry, Indian Institute of Technology,

Roorkee 247 667, India

e-mail: udaipfcy@iitr.ernet.in

T. Weyhermüller

Max-Planck-Institut für Bioanorganische Chemie,

Stifstrasse 34-36, 45470 Mulheim an der Ruhr, Germany

\section{Introduction}

A large number of $\mathrm{Zn}^{2+}$ containing hydrolytic enzymes are known which catalyze the hydrolysis or hydration reactions [1-3]. Among these, some well-studied hydrolases arecarbonic anhydrase (CA), carboxypeptidase A (CPA), angiotensin-converting enzymes, alkaline phosphatase, and the lyases [4-7]. The active site of carbonic anhydrase consists of a monomeric zinc ion, coordinated to three histidyl nitrogen atoms and a water molecule. The well-accepted mechanism involves deprotonation of the coordinated water molecule to generate a hydroxide ion on the zinc, which reacts with $\mathrm{CO}_{2}$ to give bicarbonate. While the zinc-containing carbonic anhydrase is the most effective, the zinc ion in this enzyme has been substituted with other divalent metal ions. Some of these metal-substituted carbonic anhydrases are also effective for the hydration of $\mathrm{CO}_{2}$ with the order as$\mathrm{Zn}(\mathrm{II})>\mathrm{Co}$ (II) $\gg \mathrm{Ni}$ (II) $\approx \mathrm{Mn}(\mathrm{II})>\mathrm{Cu}$ (II) $\approx 0 . \quad$ This order of reactivity suggested that the cobalt substituted carbonic anhydrase is less effective than zinc-containing carbonic anhydrase but more effective than other metal substituted carbonic anhydrases. In the above-mentioned hydrolytic enzymes, it is well known that the active species in hydration/hydrolytic reaction is the mononuclear hydroxide. Various examples of the hydrolytic reactions catalyzed by cobalt(III) complexes are available in the literature [8-11] but to the best of our knowledge there is no example with cobalt(II) complexes.

Attempts to mimic the metal coordination environment in carbonic anhydrase and other zinc-containing enzymes were met with limited success [12-14] before the first report of $\mathrm{LZnOH}$, where $\mathrm{L}=\mathrm{KHB}\left(3{ }^{\mathrm{t}} \mathrm{Bu}-5-\mathrm{Mepz}\right)_{3}$ [15]. Also, a series of structurally characterized binuclear hydroxo complexes, capable of fixing the atmospheric carbon dioxide, has been reported by Kitajima et al. [16]. 
The structurally characterized mononuclear hydroxo complexes with pyrazolylborate are limited in the literature. Hikichi et al. reported the crystal structure of mononuclear iron hydroxide in 1997 [17], whereas Fujisawa and co-workers reported the crystal structure of mononuclear copper hydroxide having pyrazolylborate as supporting ligand [18]. The present paper reports the preparation of a cobalt(II) hydroxide complex and its reaction with carbon dioxide and variety of different esters. The study suggested that the present cobalt(II) hydroxo complex is capable of both $\mathrm{CO}_{2}$ hydration as well as ester hydrolysis.

\section{Experimental}

Materials and methods

All solvents used were purified by literature methods [19]. The cobalt nitrate hexahydrate (reagent grade) was purchased from E. Merck. The other reagents of the highest grade commercially available were used without further purification. All reactions were carried out under nitrogen. The potassium salt of hydrotris(3-tert-butyl-5-isopropylpyrazol-1-yl)borate $\left[\mathrm{KHB}\left(3-{ }^{\mathrm{t}} \mathrm{Bu}-5-{ }^{\mathrm{i}} \mathrm{Prpz}\right)_{3}\right]$ [20] $\mathbf{1}$ and $\left[\mathrm{Co}\left(\mathrm{HB}\left(3,5-{ }^{\mathrm{i}} \mathrm{Pr}_{2} \mathrm{pz}\right)_{3}\right)\right]_{2}(\mathrm{OH})_{2} 2$ were prepared by literature method [16]. IR measurements were carried out in the range of $400-4,000 \mathrm{~cm}^{-1}$ as $\mathrm{KBr}$ pellets using PerkinElmer 2000 FT-IR spectrometer. The electronic spectra were recorded on a Lambda 35 Perkin Elmer UV-visible spectrometer. Mass spectra were recorded on a Finnigan MAT 8200 instrument (for the EI spectra, $70 \mathrm{eV}$ ). Temperature-dependent magnetic susceptibilities of powdered samples were measured by using a SQUID magnetometer (Quantum Design) at $1.0 \mathrm{~T}(2-290 \mathrm{~K})$. Corrections for underlying diamagnetism were made by using tabulated Pascal constants. The X-ray data collections for $\mathbf{4 , 5}$, and $\mathbf{6}$ were performed on Siemens Smart-CCD diffractometer, while for $\mathbf{7}$ on Bruker Smart-CCD diffractometer.

\section{Preparation of $\left[\mathrm{Co}\left\{\mathrm{HB}\left(3-^{t} \mathrm{Bu}-5-{ }^{i} \mathrm{Prpz}\right)_{3}\right\}\left(\mathrm{NO}_{3}\right)\right](3)$}

A solution of $\mathrm{Co}\left(\mathrm{NO}_{3}\right)_{2} \cdot 6 \mathrm{H}_{2} \mathrm{O}(0.58 \mathrm{~g}, 2.00 \mathrm{mmol})$ in methanol $(25 \mathrm{~mL})$ was added to a stirred solution of [KHB $\left.\left(3{ }^{\mathrm{t}}{ }^{\mathrm{Bu}}-5-{ }^{\mathrm{i}} \mathrm{Prpz}\right)_{3}\right](1.09 \mathrm{~g}, 2.00 \mathrm{mmol})$ in dichloromethane $(15 \mathrm{~mL})$. The mixture was stirred for $4 \mathrm{~h}$. Then, the precipitate was filtered off and dried under vacuum for several hours. Yield $0.46 \mathrm{~g}(37 \%)$. Anal. Calcd. for $\mathrm{C}_{30} \mathrm{H}_{52} \mathrm{~N}_{7} \mathrm{O}_{3} \mathrm{BCo}$ : C, 57.3; H, 8.3; N, 15.6. Found: C, 58.6; $\mathrm{H}, 8.8 ; \mathrm{N}, 15.5$. IR $\left(\mathrm{KBr}, \mathrm{cm}^{-1}\right): v(\mathrm{BH}) 2593, v_{\text {as }}\left(\mathrm{NO}_{3}\right)$ 1528, $v_{\mathrm{s}}\left(\mathrm{NO}_{3}\right)$ 1275. UV-vis (toluene, $\mathrm{nm}, \varepsilon / \mathrm{M}^{-1} \mathrm{~cm}^{-1}$ ): 292 (1188), 602 (330). EI-MS $(\mathrm{m} / \mathrm{z}): 628\left[\mathrm{Co}\left(\mathrm{NO}_{3}\right)\{\mathrm{HB}(3-\right.$ $\left.\left.\left.{ }^{\mathrm{t}} \mathrm{Bu}-5-{ }^{\mathrm{i}} \mathrm{Prpz}\right)_{3}\right\}\right], 565\left[\mathrm{Co}\left\{\mathrm{HB}\left(3-{ }^{\mathrm{t}} \mathrm{Bu}-5-{ }^{\mathrm{i}} \mathrm{Prpz}\right)_{3}\right\}\right]^{+}$. Magnetic moment (290 K): 3.70 B.M.
Preparation of $\left[\mathrm{Co}\left\{\mathrm{HB}\left(3-{ }^{\mathrm{t}} \mathrm{Bu}-5-{ }^{i} \mathrm{Prpz}\right)_{3}\right\}(\mathrm{OH})\right](4)$

A solution of $3(0.46 \mathrm{~g}, 0.73 \mathrm{mmol})$ in toluene $(20 \mathrm{~mL})$ was treated with $1 \mathrm{~N}$ aqueous solution of $\mathrm{NaOH}(10 \mathrm{~mL})$ for $1 \mathrm{~h}$ under nitrogen. The aqueous layer was separated and the solvent layer was dried on anhydrous sodium sulfate for $30 \mathrm{~min}$. The deep blue color solution was obtained after filtration and the solvent was removed under vacuum. The resultant solid was recrystallized from a mixture of $\mathrm{CH}_{2} \mathrm{Cl}_{2} / \mathrm{CH}_{3} \mathrm{CN}$ at $-20{ }^{\circ} \mathrm{C}$. Yield $0.20 \mathrm{~g}(47 \%)$. Anal. Calcd. for $\mathrm{C}_{30} \mathrm{H}_{53} \mathrm{~N}_{6} \mathrm{OBCo}$ : C, 61.8; $\mathrm{H}, 9.2 ; \mathrm{N}, 14.4$. Found: $\mathrm{C}, 61.6 ; \mathrm{H}, 9.1 ; \mathrm{N}, 14.3$. IR $\left(\mathrm{KBr} \mathrm{cm}^{-1}\right): v(\mathrm{BH})$ $2552 v(\mathrm{OH}) 3670$. UV-vis (toluene, $\mathrm{nm}, \varepsilon / \mathrm{M}^{-1} \mathrm{~cm}^{-1}$ ): 532 (191), 667 (830). EI-MS (m/z): 566 [4-OH]. Magnetic moment $(290 \mathrm{~K}): 4.48$ B.M.

\section{Preparation of $\left[\mathrm{Co}\left\{\mathrm{HB}\left(3-{ }^{t} \mathrm{Bu}-5-{ }^{i} \mathrm{Prpz}\right)_{3}\right\}\right]_{2}\left(\mathrm{CO}_{3}\right)(5)$}

Under nitrogen, the complex $4(0.20 \mathrm{~g}, 0.34 \mathrm{mmol})$ was dissolved in toluene $(30 \mathrm{~mL})$ in a Schlenk tube. The atmosphere in the tube was replaced with pure $\mathrm{CO}_{2}$ and the solution was stirred at room temperature for $2 \mathrm{~h}$. The solvent was then removed under vacuum and the resulting solid was recrystallized from $\mathrm{CH}_{3} \mathrm{CN} / \mathrm{CH}_{2} \mathrm{Cl}_{2}$ at $-20{ }^{\circ} \mathrm{C}$. Yield $0.20 \mathrm{~g}(49 \%)$. Anal. Calcd. for $\mathrm{C}_{61} \mathrm{H}_{104} \mathrm{~N}_{12} \mathrm{O}_{3} \mathrm{~B}_{2} \mathrm{Co}_{2}$ : C, 61.4; H, 8.8; N, 14.1. Found: C, 60.7; H, 8.6; N, 13.9. IR $\left(\mathrm{KBr} \mathrm{cm}^{-1}\right): v(\mathrm{BH}) 2566, v(\mathrm{C}=\mathrm{O}) 1604$. UV-vis (toluene, $\left.\mathrm{nm}, \varepsilon / \mathrm{M}^{-1} \mathrm{~cm}^{-1}\right): 536$ (371), 589 (649), 667 (1632). EIMS $(m / z): 1193\left[\mathrm{Co}\left\{\mathrm{HB}\left(3-{ }^{\mathrm{t}} \mathrm{Bu}-5-{ }^{\mathrm{i}} \mathrm{Prpz}\right)_{3}\right\}\right]_{2}\left(\mathrm{CO}_{3}\right), 566$ $\left[\mathrm{Co}\left\{\mathrm{HB}\left(3-{ }^{\mathrm{t}} \mathrm{Bu}-5-{ }^{\mathrm{i}} \mathrm{Prpz}\right)_{3}\right\}\right]^{+}$. Magnetic moment $(290 \mathrm{~K})$ : 6.51 B.M.

Preparation of $\left[\mathrm{Co}\left\{\mathrm{HB}\left(3{ }^{\mathrm{t}} \mathrm{Bu}^{-5}{ }_{-}{ }^{i} \mathrm{Prpz}\right)_{3}\right\}\left(\mathrm{OC}_{6} \mathrm{H}_{4}-\mathrm{p}-\mathrm{NO} \mathrm{O}_{2}\right)\right]$ (6)

A solution of complex $4(0.05 \mathrm{~g}, 0.09 \mathrm{mmol})$ in toluene $(10 \mathrm{~mL})$ was added to a stirred solution of sodium4-nitrophenylacetate $(0.02 \mathrm{~g}, 0.11 \mathrm{mmol})$ in toluene $(10 \mathrm{~mL})$. The mixture was stirred for $2 \mathrm{~h}$. After removal of salt by filtration, the compound was dried under vacuum and recrystallized from $\mathrm{CH}_{3} \mathrm{CN}$ at $-20{ }^{\circ} \mathrm{C}$. Yield $0.02 \mathrm{~g}$ (33\%). Anal. Calcd. for $\mathrm{C}_{36} \mathrm{H}_{56} \mathrm{~N}_{7} \mathrm{O}_{3} \mathrm{BCo}: \mathrm{C}, 61.4 ; \mathrm{H}, 8.0$; N, 13.9. Found: C, 60.2; H, 7.9; N, 12.9. IR $\left(\mathrm{KBr}, \mathrm{cm}^{-1}\right)$ : $v(\mathrm{BH}) 2569, v(\mathrm{~N}=\mathrm{O}) 1583,1312$. UV-vis (toluene, $\mathrm{nm}$, $\varepsilon / \mathrm{M}^{-1} \mathrm{~cm}^{-1}$ ): 361 (7187), 608 (282), 671 (799). EI-MS $(\mathrm{m} / \mathrm{z}): 704\left[\mathrm{Co}\left\{\mathrm{HB}\left(3-{ }^{\mathrm{t}} \mathrm{Bu}-5-{ }^{\mathrm{i}} \mathrm{Prpz}\right)_{3}\right\}\left(\mathrm{OC}_{6} \mathrm{H}_{4}-\mathrm{pNO}_{2}\right)\right], 566$ $\left[\mathrm{Co}\left\{\mathrm{HB}\left(3-{ }^{\mathrm{t}} \mathrm{Bu}-5-{ }^{\mathrm{i}} \operatorname{Prpz}\right)_{3}\right\}\right]^{+}$.

\section{Preparation of $\left[\mathrm{Co}\left\{\mathrm{HB}\left(3,5-^{i} \mathrm{Pr}_{2} \mathrm{pz}\right)_{3}\right\}\left(\mathrm{OC}_{6} \mathrm{H}_{4}-\mathrm{p}\right.\right.$ -} $\left.\left.\mathrm{NO}_{2}\right)\left(\mathrm{CH}_{3} \mathrm{CN}\right)_{2}\right]$ (7)

To the solution of complex $2(0.92 \mathrm{~g}, 0.85 \mathrm{mmol})$ in toluene $(20 \mathrm{~mL})$, the solution of 4-nitrophenyltrifluoroacetate 
$(0.2 \mathrm{~g}, 0.85 \mathrm{mmol})$ in toluene $(15 \mathrm{~mL})$, was added dropwise. The mixture was stirred for $6 \mathrm{~h}$. Filtration and evaporation of solvent under vacuum resulted the red color compound which upon recrystallization from acetonitrile at $4{ }^{\circ} \mathrm{C}$ afforded the red color crystals suitable for X-ray data collection. Yield $0.31 \mathrm{~g}$ (65\%). Anal. Calcd. for $\mathrm{C}_{41} \mathrm{H}_{62} \mathrm{~N}_{11} \mathrm{O}_{3} \mathrm{BCo}$ : C, 62.93; H, 7.98; N, 21.2. Found: C, 60.20; H, 7.90; N, 12.85. IR ( $\left.\mathrm{KBr}, \mathrm{cm}^{-1}\right): v(\mathrm{BH}) 2569$, $v(\mathrm{CN}) 2279, v(\mathrm{~N}=\mathrm{O}) 1583,1312$. UV-vis (toluene, $\mathrm{nm}, \varepsilon /$ $\mathrm{M}^{-1} \mathrm{~cm}^{-1}$ ): 570 (287), 730 (82).

X-ray data collections and structural determinations

Crystals suitable for $\mathrm{X}$-ray analysis of $\mathbf{4}$ and $\mathbf{5}$ were obtained from $\mathrm{CH}_{3} \mathrm{CN} / \mathrm{CH}_{2} \mathrm{Cl}_{2}$ solutions and of $\mathbf{6}$ from $\mathrm{CH}_{3} \mathrm{CN}$ at $-20{ }^{\circ} \mathrm{C}$. Single crystal of $\mathbf{2}, \mathbf{5} \cdot 3 \mathrm{CH}_{2} \mathrm{Cl}_{2}$. $\mathrm{CH}_{3} \mathrm{CN}$, and $\mathbf{6} \cdot 2 \mathrm{CH}_{3} \mathrm{CN}$ were coated with perfluoropolyether, picked up with glass fibers and mounted on a Siemens Smart-CCD diffractrometer. Graphite monochromated Mo $\mathrm{K} \alpha$ radiation $(\lambda=0.71073 \AA)$ was used throughout. Crystallographic data are listed in Table 1. Cell constants were obtained from a least squares fit of diffraction angles of several thousand strong reflections. Intensity data were corrected for Lorentz and polarization effects. Crystal faces were determined and the face-indexed correction routine embedded in SHELX TL [21, 22] was used to account for absorption. The SHELX TL software package was used for solution, refinement, and artwork of the structure. Non-hydrogen atoms were placed at calculated positions and refined as riding atoms with isotropic displacement parameters. Single crystal diffraction studies for $7 \cdot 4 \mathrm{CH}_{3} \mathrm{CN}$ was carried out on a Bruker Smart CCD diffractometer with $\mathrm{Mo} \mathrm{K} \alpha(\lambda=0.71073 \AA)$ sealed tube at $25{ }^{\circ} \mathrm{C}$. Crystal structures were solved by direct methods and in anisotropic approximation refined using the SHELX TL package [21, 22]. Hydrogen atoms were constrained by rigid model. Complex $\mathbf{4}$ was found to be disordered on a crystallographic mirror plane. A split

Table 1 Crystal data and structure refinement for $\left[\mathrm{Co}\left\{\mathrm{HB}\left(3-{ }^{\mathrm{t}} \mathrm{Bu}-5-{ }^{\mathrm{i}} \mathrm{Prpz}\right)_{3}\right\}(\mathrm{OH})\right](\mathbf{4}), \quad\left[\mathrm{Co}\left\{\mathrm{HB}\left(3-{ }^{\mathrm{t}} \mathrm{Bu}-5-{ }^{\mathrm{i}} \mathrm{Prpz}_{3}\right]_{2}\left(\mathrm{CO}_{3}\right)\right]\left(\mathbf{5} \cdot 3 \mathrm{CH} \mathrm{Cl}_{2}\right.\right.$. $\left.\mathrm{CH}_{3} \mathrm{CN}\right),\left[\mathrm{Co}\left\{\mathrm{HB}\left(3-{ }^{\mathrm{t}} \mathrm{Bu}-5-{ }^{\mathrm{i}} \mathrm{Prpz}\right)_{3}\right\}\left(\mathrm{OC}_{6} \mathrm{H}_{4}-\mathrm{pNO}_{2}\right)\right]\left(6 \cdot 2 \mathrm{CH}_{3} \mathrm{CN}\right),\left[\mathrm{Co}\left\{\mathrm{HB}\left(3,5{ }^{\mathrm{i}} \mathrm{Prpz}\right)\right\}\left(\mathrm{OC}_{6} \mathrm{H}_{4}-\mathrm{pNO}_{2}\right)\left(\mathrm{CH}_{3} \mathrm{CN}\right)_{2}\right](7 \cdot 4 \mathrm{CH} 3 \mathrm{CN})$

\begin{tabular}{|c|c|c|c|c|}
\hline Complex & (4) & $\left(5 \cdot 3 \mathrm{CH}_{2} \mathrm{Cl}_{2} \cdot \mathrm{CH}_{3} \mathrm{CN}\right)$ & $\left(6 \cdot 2 \mathrm{CH}_{3} \mathrm{CN}\right)$ & $\left(7 \cdot 4 \mathrm{CH}_{3} \mathrm{CN}\right)$ \\
\hline Empirical formula & $\mathrm{C}_{30} \mathrm{H}_{53} \mathrm{~N}_{6} \mathrm{OBCo}$ & $\mathrm{C}_{66.3} \mathrm{H}_{113.3} \mathrm{~N}_{13.30} \mathrm{O}_{3} \mathrm{Cl}_{5.40} \mathrm{~B}_{2} \mathrm{Co}_{2}$ & $\mathrm{C}_{40} \mathrm{H}_{62} \mathrm{~N}_{9} \mathrm{O}_{3} \mathrm{BCo}$ & $\mathrm{C}_{45} \mathrm{H}_{68} \mathrm{~N}_{13} \mathrm{O}_{3} \mathrm{BCo}$ \\
\hline Formula weight & 583.52 & $1,475.71$ & 786.73 & 908.86 \\
\hline Temperature $(\mathrm{K})$ & $298(2)$ & $298(2)$ & $298(2)$ & $298(2)$ \\
\hline Wavelength $(\AA)$ & 0.7107 & 0.7107 & 0.7107 & 0.7107 \\
\hline Crystal system & Orthorhombic & Triclinic & Monoclinic & Monoclinic \\
\hline Space group & $\mathrm{Cmc} 2_{1}$ & $\mathrm{P}-1$ & $\mathrm{P} 2{ }_{1} / \mathrm{n}$ & $\mathrm{P} 2(1)$ \\
\hline \multicolumn{5}{|l|}{ Unit cell dimensions } \\
\hline$a(\AA)$ & $16.3208(12)$ & $9.8752(4)$ & $9.6256(8)$ & $11.702(5)$ \\
\hline$b(\AA)$ & $10.2252(8)$ & $12.5748(6)$ & $25.199(3)$ & $12.478(5)$ \\
\hline$c(\AA)$ & $19.669(2)$ & $17.3364(8)$ & $18.070(2)$ & $17.835(7)$ \\
\hline$V\left(\AA^{3}\right)$ & $3,282.4(5)$ & $1,925.96(15)$ & $4,296.7(8)$ & $2,545.1(18)$ \\
\hline$Z$ & 4 & 1 & 4 & 2 \\
\hline$\rho$ (calcd.) $\left(\mathrm{mg} \mathrm{m}^{-3}\right)$ & 1.181 & 1.272 & 1.216 & 1.186 \\
\hline$\mu\left(\mathrm{m}^{-1}\right)$ & 0.554 & 0.669 & 0.446 & 0.387 \\
\hline$F(000)$ & 1,260 & 784 & 1,684 & 970 \\
\hline Crystal size $\left(\mathrm{mm}^{3}\right)$ & $0.12 \times 0.05 \times 0.03$ & $0.27 \times 0.09 \times 0.09$ & $0.10 \times 0.09 \times 0.03$ & $0.22 \times 0.19 \times 0.13$ \\
\hline$\theta$ range for data collection & $\left({ }^{\circ}\right) 3.9$ to 27.5 & 3.23 to 31.0 & 3.25 to 21.0 & 1.17 to 25.5 \\
\hline$h / k / l(\max , \min )$ & $-22,23 /-14,14 /-28,27$ & $-14,14 /-18,18 /-23,25$ & $-9,9 /-25,25 /-17,18$ & $-14,11 /-15,14 /-22,21$ \\
\hline Reflection collected & 3,754 & 12,206 & 4,591 & 9,197 \\
\hline Unique & 2,908 & 8,597 & 3,218 & 7,875 \\
\hline Completeness (\%) & 96 & 99.4 & 99.5 & 97 \\
\hline Absorption correction & Gaussian & Gaussian & Gaussian & \\
\hline Data/restraints/parameters & $2,908 / 17 / 214$ & $8,597 / 22 / 473$ & $3,218 / 55 / 537$ & $7,875 / 1 / 589$ \\
\hline Goodness-of-fit on $F^{2}$ & 1.080 & 1.035 & 1.077 & 1.115 \\
\hline $\begin{array}{l}\text { Final } R 1, w R 2 \text { indices } \\
\quad[I>2 \sigma(I)]\end{array}$ & $0.0518,0.0823$ & $0.0722,0.1848$ & $0.0635,0.1435$ & $0.0676,0.1490$ \\
\hline$R 1, w R 2$ indices (all data) & $0.0794,0.0910$ & $0.1103,0.2125$ & $0.1034,0.1641$ & $0.0809,0.1697$ \\
\hline
\end{tabular}


model was applied to two i-propyl groups containing C6, $\mathrm{C} 7, \mathrm{C} 8$, and $\mathrm{C} 26, \mathrm{C} 27, \mathrm{C} 28$. The split positions were refined with equal occupation factors of 0.5 , restrained $\mathrm{C}-$ $\mathrm{C}$ bond length, and equal anisotropic displacement parameters for corresponding split positions using SADI and EADP instructions of ShelXL. An electron density search around $\mathrm{O} 1$ suggested that the hydroxo proton is not exactly located on the crystallographic mirror plane. Its position (off the mirror plane) was therefore refined with an occupation factor of 0.5 .

The bridging carbonate group in compound $\mathbf{5}$ is located on a crystallographic center of inversion and therefore leads to disorder. A test in acentric space group P1 (No.1) showed that the disorder still persists and therefore refinement in P-1 (No.2) is adequate. The occupation factors of the central carbon, $\mathrm{C} 60$, and of $\mathrm{O} 1$ were set to 0.5 but no further restrictions were applied. The refinement reveals that the carbonate anion binds in an asymmetrical fashion, bidentate to one cobalt and unidentate to the other. The compound contains dichloromethane and acetonitrile molecules of crystallization. One position was found to be occupied with both solvents and two split positions were refined with given total occupation factors of 0.5 each. To account for the disorder, positions of $\mathrm{Cl} 3$ and N90 were fixed to an identical position using EXYZ and anisotropically refined using the EADP instructions of ShelXL. Remaining atoms of the two solvents were isotropically refined since their positions are not well defined. $\mathrm{Cl} 4$ was further split on two sub positions with occupation of 0.25 each. $\mathrm{C}-\mathrm{Cl}$ and $\mathrm{Cl}-\mathrm{Cl}$ distances were restrained to be equal within errors using the SADI instruction.

All three isopropyl groups in complex $\mathbf{6}$ and an acetonitrile molecule of crystallization were found to be disordered over two sites. The isopropyl groups are disordered by rotation and therefore two split positions were refined for their methyl carbon positions. The disorder of the isopropyl groups leads to disorder of an acetonitrile molecule which was also split. The two resulting split parts were refined with an occupation ratio of about 0.61:0.39. SADI and EADP restraints were used.

Kinetics experiments for ester hydrolysis reaction in non-aqueous solution

Kinetic measurements for the hydrolysis of different esters were performed with a Lambda 35 Perkin Elmer UV-visible spectrophotometer by following the increases at the $360 \mathrm{~nm}$ absorption due to release of 4-nitrophenolate. The temperature was controlled at $25^{\circ} \mathrm{C}$ in all experiments. Acetonitrile solution of esters $(6.0 \mathrm{mM})$ and catalyst $(\mathbf{2} / \mathbf{4})$ $(6.0 \mathrm{mM})$ were prepared as stock solution. The cell was prepared by taking ester $(50.0 \mu \mathrm{L})$, catalyst $(500.0 \mu \mathrm{L})$, and solvent acetonitrile $(1,450 \mu \mathrm{L})$. The absorption data were recorded immediately after mixing the solution and followed until the formation of 4-nitrophenolate ion completed (means no change in the spectra was observed) [23]. Rate constants were calculated according to the published procedure [24, 25].

\section{Results and discussion}

Hydrolysis of esters

Structural determination of the mononuclear cobalt(II) hydroxo complex 4 prompted us to investigate the role of this complex and previously prepared binuclear cobalt(II) $\mu$-hydroxo complex 2 in both carboxylate as well as phosphate esters hydrolysis. The ester hydrolysis was monitored spectrophotometrically. Figure 1 shows a representative example of the released 4-nitrophenolate at $360 \mathrm{~nm}$ for the reaction of 2 . The absorbance $\left(\mathrm{A}_{\mathrm{t}}\right)$ at $360 \mathrm{~nm}$ was recorded at $5 \mathrm{~min}$ intervals over $60 \mathrm{~min}$. The values of pseudo first order rate constants $\mathrm{k}$ were obtained from the slopes of the plots of $\log \left(\mathrm{A}_{\mathrm{int}}-\mathrm{A}\right)$ versus time. Plots of $\mathrm{k}$ versus five different concentrations $(1.5-5.25 \mathrm{mM})$ of $2 / 4$ were linear confirming first order dependence on catalysts. The second order rate constant obtained according to $\mathrm{k}=\mathrm{k}_{2}$ [catalyst]. Figure 2 shows the plot of the $\mathrm{k}$ use for the hydrolysis of 4-nitrophenyltrifluoroacetate at various concentrations of 2 . Table 2 summarizes the first and second order rate constants for hydrolysis of esters obtained from the reaction of substrate and 2/4 complex in stoichiometric ratio. The results showed that both $\mathbf{2}$ and $\mathbf{4}$ can catalyze the hydrolysis

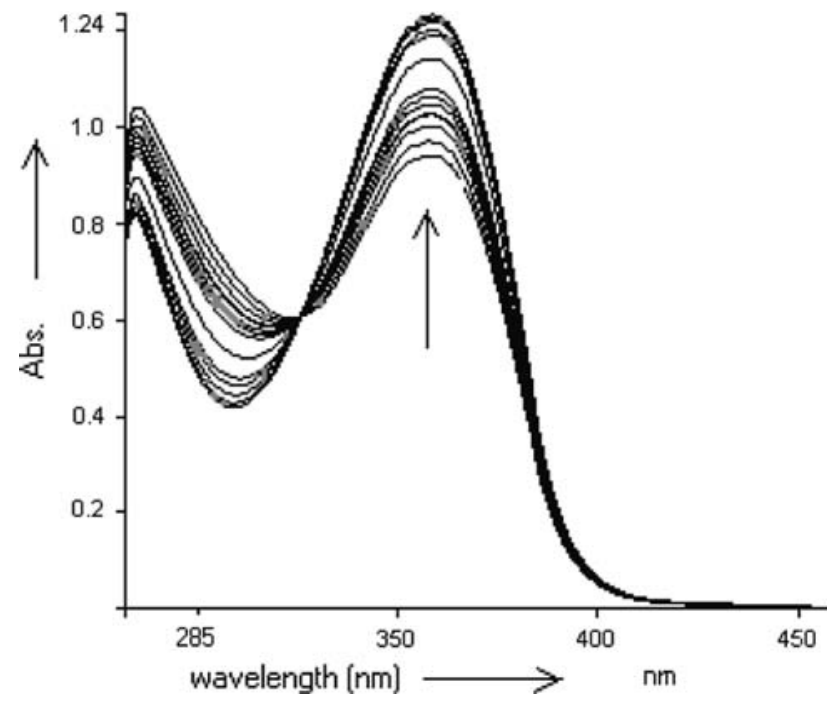

Fig. 1 A representative figure showing the increase in the absorbance of the released 4-nitrophenolate at $360 \mathrm{~nm}$ for the reaction of 2 $(1.5 \mathrm{mM})$ with 4-nitrophenyl trifluoroacetate $(0.15 \mathrm{mM})$ in $\mathrm{CH}_{3} \mathrm{CN}$ at $300 \mathrm{~K}$ 


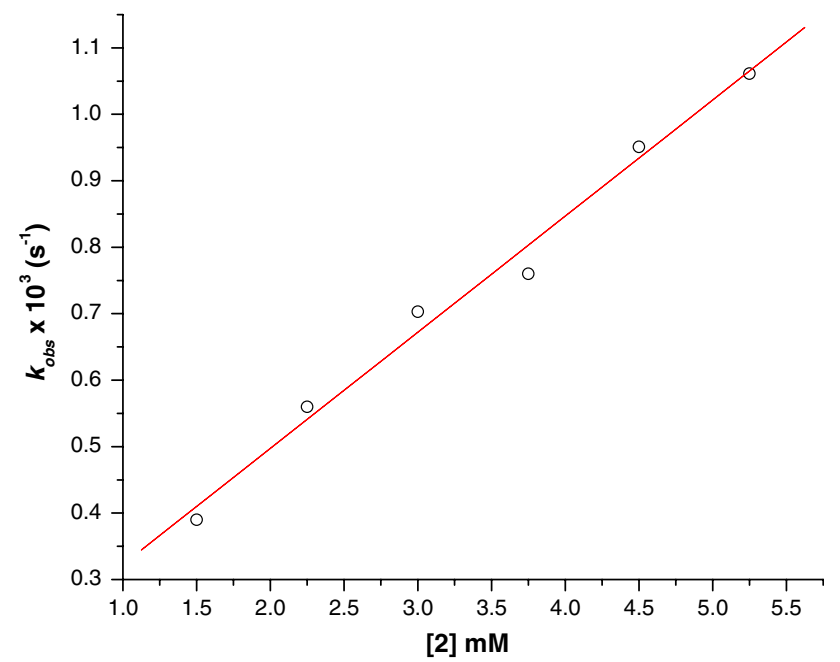

Fig. 2 Plot of the $\mathrm{k}$ values for the hydrolysis of 4-nitrophenyl trifluoroacetate at various concentrations of 2 in $\mathrm{CH}_{3} \mathrm{CN}$ at $300 \mathrm{~K}$

of phosphate as well as carboxylate ester. Like other researchers [26-28] we too observe that with Tp ligand system also, the hydrolysis of both phosphate as well as carboxylate ester is slower with catalyst $\mathbf{4}$ in comparison to 2. The $k_{2}$ values obtained by $\mathbf{4}$ are smaller than that of $\mathbf{2}$. Among the various ester taken in the present study, the $\mathrm{k}$ value is greater for 4-nitrophenyllaurate and lowest for 4-nitrophenylacetate with both 2 and $\mathbf{4}$. This may be due to the fact that electron donating group present on ester facilitates the hydrolysis, whereas the electronic withdrawing group causes slow hydrolysis. A possible mechanism is shown in Scheme 1. Kinetic experiments indicated the dissociation of $\mathbf{2}$ to monomeric as nucleophile to attack the ester [29]. In the hydrolysis of both carboxylate as well as phosphate esters catalyzed by $\mathbf{2}$ and $\mathbf{4}$, the carbonyl oxygen of the ester may be bound to the metal atom and the hydroxide ligand attacks the activated carbonyl group and then releases 4-nitrophenolate. The present findings may serve as model for cobalt(II) substituted zinc(II)-containing enzymes, viz., phosphatases [30].

We have also attempted the isolation and structural characterization of the ester hydrolysis products especially with 4-nitrophenyltrifluoroacetate (NPTFA) and 4-nitrophenylacetate (NPA) with complexes $\mathbf{2}$ and $\mathbf{4}$, respectively.

\section{Molecular structure of $\left[\mathrm{Co}\left\{\mathrm{HB}\left(3-{ }^{t} \mathrm{Bu}-5{ }^{i}{ }^{\mathrm{Prpp}}\right)_{3}\right\}(\mathrm{OH})\right]$ (4)}

The complex 4 was prepared by the reaction of a toluene solution of 3 with $1 \mathrm{~N}$ aqueous solution of $\mathrm{NaOH}$ (Scheme 2). Single crystals of $\mathbf{4}$ suitable for $\mathrm{X}$-ray analysis were obtained by cooling the mixture of $\mathrm{CH}_{3} \mathrm{CN} / \mathrm{CH}_{2} \mathrm{Cl}_{2}$ (50:50) solution to $-20{ }^{\circ} \mathrm{C}$. Figure 3 shows a molecular structure of the 4. The cobalt, oxygen, and one of the pyrazole rings (containing N22) sit on a crystallographic mirror plane and this leads to two possible disordered positions for the hydrogen of the $\mathrm{OH}$. The cobalt atom in complex $\mathbf{4}$ is in slightly distorted tetrahedral environment as evidenced by the three small $\mathrm{N}$ (pyrazole)-Co-N(pyrazole) bond angles (average, $93.7^{\circ}$ ) and coordinated by the $\mathrm{N} 3 \mathrm{O} 1$ donor set. The $\mathrm{Co}-\mathrm{O}$ distance is shorter than the averaged Co-N distance by $0.18 \AA$. The average N(pyrazole)-Co-N(pyrazole) bond angle in $\mathbf{4}$ is larger than the $\mathrm{N}$ (pyrazole)-Co-N(pyrazole) bond angles (average $87.3^{\circ}$ ) in the square pyramidal cobalt complex 2 and also than in the recently reported five coordinate mononuclear hydroxo cobalt(II) complex with the $\mathrm{N}$ (pyrazole)-Co-N(pyrazole) bond angles (average $85.8^{\circ}$ ) $\left[31,{ }^{1} 32\right]$. The average $\mathrm{O}-\mathrm{Co}-$ $\mathrm{N}$ (pyrazole) bond angle $\left(122.6^{\circ}\right)$ in complex 4 is smaller than the average $\mathrm{O}-\mathrm{Co}-\mathrm{N}$ (pyrazole) bond angles (average $125.3^{\circ}$ ) present in 2 . The Co-O distance of 1.854 (3) $\AA$ is slightly shorter than the $\mathrm{Co}-\mathrm{O}$ bond distance in square pyramidal cobalt hydroxo complex [16]. Furthermore the evidence for the presence of the hydroxo group was provided by the appearance of $v(\mathrm{OH})$ band at $3,670 \mathrm{~cm}^{-1}$ in the IR spectrum of $\mathbf{4}$. Thus, the complex $\mathbf{4}$ is mononuclear terminal hydroxo cobalt(II). To the best of our knowledge, this is the second example of a structurally characterized mononuclear tetrahedral cobalt (II) hydroxo complex $\left[31,{ }^{2}\right.$ 32].

\section{Molecular structure of $\left.\left[\mathrm{Co}\left\{\mathrm{HB}\left(3{ }^{t}{ }^{\mathrm{B} u}-5{ }^{i}{ }^{\mathrm{Prpz}}\right)_{3}\right\}\right]_{2}\left(\mathrm{CO}_{3}\right)\right]$} (5)

The reaction of $\mathbf{4}$ with carbon dioxide yielded complex $\mathbf{5}$. When the toluene solution of $\mathbf{4}$ was exposed to $1 \mathrm{~atm}$ of $\mathrm{CO}_{2}$, pronounced color change from red to purple blue was observed (Scheme 2). Due to its low solubility, however, the crystallized product was ( $\mu$-carbonato) dicobalt complex 5 instead of mononuclear hydrogen carbonate complex $\left[\mathrm{N}_{3} \mathrm{Co}-\left(\mathrm{HCO}_{3}\right)\right]$. The crystal structure of the complex $\mathbf{5}$ was determined by X-ray crystallography and the molecular structure is given in Fig. 4. The selected bond lengths and bond angles are summarized in Table 3 . As shown in Fig. 4, complex 5 has distorted structure. The bridging carbonate anion in complex $\mathbf{5}$ is bound in an unsymmetrical fashion; it coordinates to $\mathrm{Co} 1$ in a bidentate and to Co1A in unidentate fashion. Since the molecule resides on a crystallographic center of inversion, the carbonate anion is disordered but the two orientations could be resolved satisfactorily by a 50:50 split atom model.

\footnotetext{
${ }^{1}$ Hikichi et al. have reported the synthesis of mononuclear hydroxo complex with same ligand but never succeeded in getting crystal structure. They had also observed a peak due to product formed with $\mathrm{CO}_{2}$ in mass spectral measurement.

${ }^{2}$ See footnote 1 .
} 
Table 2 First and second order rate constants for hydrolysis of esters

\begin{tabular}{|c|c|c|c|c|}
\hline \multirow[t]{3}{*}{ Substrate } & \multicolumn{4}{|l|}{ Hydroxo } \\
\hline & \multicolumn{2}{|c|}{$\mathrm{Co}_{2}(\mathrm{OH})_{2}\left\{\mathrm{HB}\left(3,5-{ }^{\mathrm{i}} \mathrm{Prpz}\right)_{3}(\mathbf{2})\right.$} & \multicolumn{2}{|c|}{$\mathrm{Co}(\mathrm{OH})\left\{\mathrm{HB}\left(3-{ }^{\mathrm{t}} \mathrm{Bu}-5-{ }^{\mathrm{i}} \mathrm{Prpz}\right)_{3}(4)\right.$} \\
\hline & $K_{\mathrm{obs}}\left(\mathrm{s}^{-1}\right)$ & $K_{2}\left(\mathrm{M}^{-1} \mathrm{~s}^{-1}\right)$ & $K_{\text {obs }}\left(\mathrm{s}^{-1}\right)$ & $K_{2}\left(\mathrm{M}^{-1} \mathrm{~s}^{-1}\right)$ \\
\hline 4-Nitrophenyl trifluoro acetate & $0.390 \times 10^{-3}$ & 0.174 & $0.125 \times 10^{-3}$ & 0.108 \\
\hline 4-Nitrophenyl acetate & $2.630 \times 10^{-3}$ & 0.270 & $0.749 \times 10^{-3}$ & 0.198 \\
\hline 4-Nitrophenyl propionate & $2.860 \times 10^{-3}$ & 0.478 & $0.980 \times 10^{-3}$ & 0.354 \\
\hline 4-Nitrophenyl caprylate & $3.640 \times 10^{-3}$ & 0.402 & $1.267 \times 10^{-3}$ & 0.287 \\
\hline 4-Nitrophenyl laurate & $4.361 \times 10^{-3}$ & 0.757 & $1.502 \times 10^{-3}$ & 0.352 \\
\hline Mono(4-nitrophenyl phosphate & $2.202 \times 10^{-3}$ & 0.626 & $0.536 \times 10^{-3}$ & 0.276 \\
\hline Bis(4-nitrophenyl phosphate & $1.060 \times 10^{-3}$ & 0.513 & $0.337 \times 10^{-3}$ & 0.212 \\
\hline Tris(4-nitrophenyl phosphate & $0.951 \times 10^{-3}$ & 0.277 & $0.201 \times 10^{-3}$ & 0.145 \\
\hline
\end{tabular}

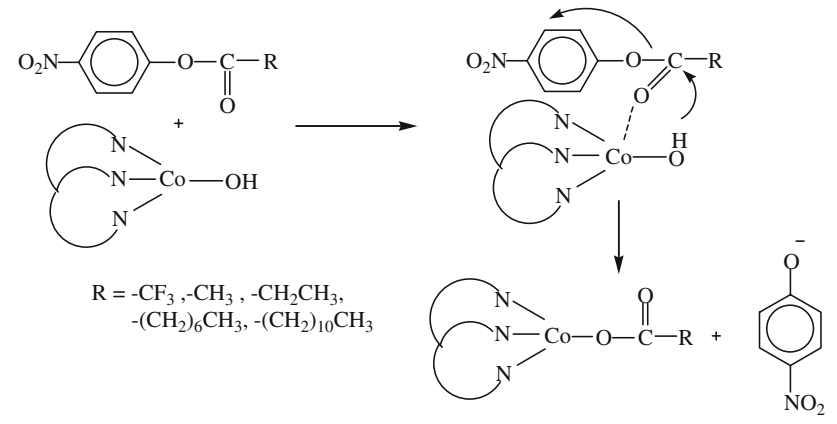

Scheme 1 The proposed mechanism for the hydrolytic cleavage of different carboxylate esters using complex $\mathbf{2}$ as catalyst

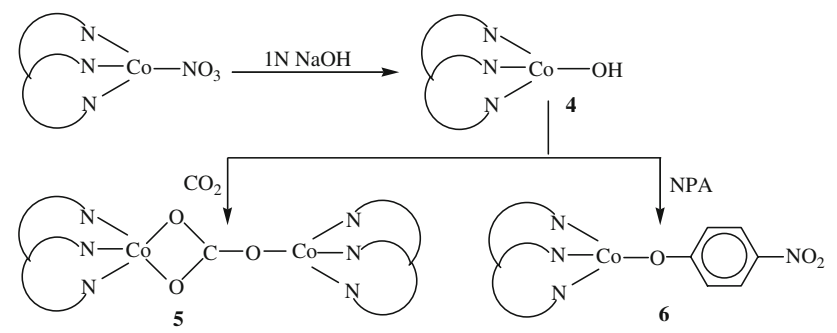

Scheme 2 Synthesis of complexes 4, 5 and 6

The $\mathrm{N}_{3} \mathrm{O}_{2}$ ligand field around $\mathrm{Co} 1$ is much distorted because the distance between the cobalt and one oxygen from the carbonate is more elongated (Co1-O1, 2.151 (4) $\AA$ ) than the other cobalt-oxygen bond distance (Co1O2, 1.972 (3) $\AA$ ). Similar type of coordination mode has been reported in literature by other workers also $\left[16,31{ }^{3}\right.$ 32]. The $\mathrm{Co}-\mathrm{N}$ bond lengths are almost equal (Co1-N2, 2.075(2); Co1-N40, 2.078(2); Co1-N21, 2.079(3) ̊) but slightly longer than the reported zinc complex [16]. In complex $\mathbf{5}$, one cobalt is five coordinate and other is four coordinate. Same type coordination environment was observed in $\left[\mathrm{Zn}\left(\mathrm{HB}\left(3,5-\mathrm{iPr} \mathrm{Pr}_{2}\right)_{3}\right]_{2}\left(\mathrm{CO}_{3}\right)\right.$ [16] but not in

$\overline{3 \text { See footnote } 1 .}$

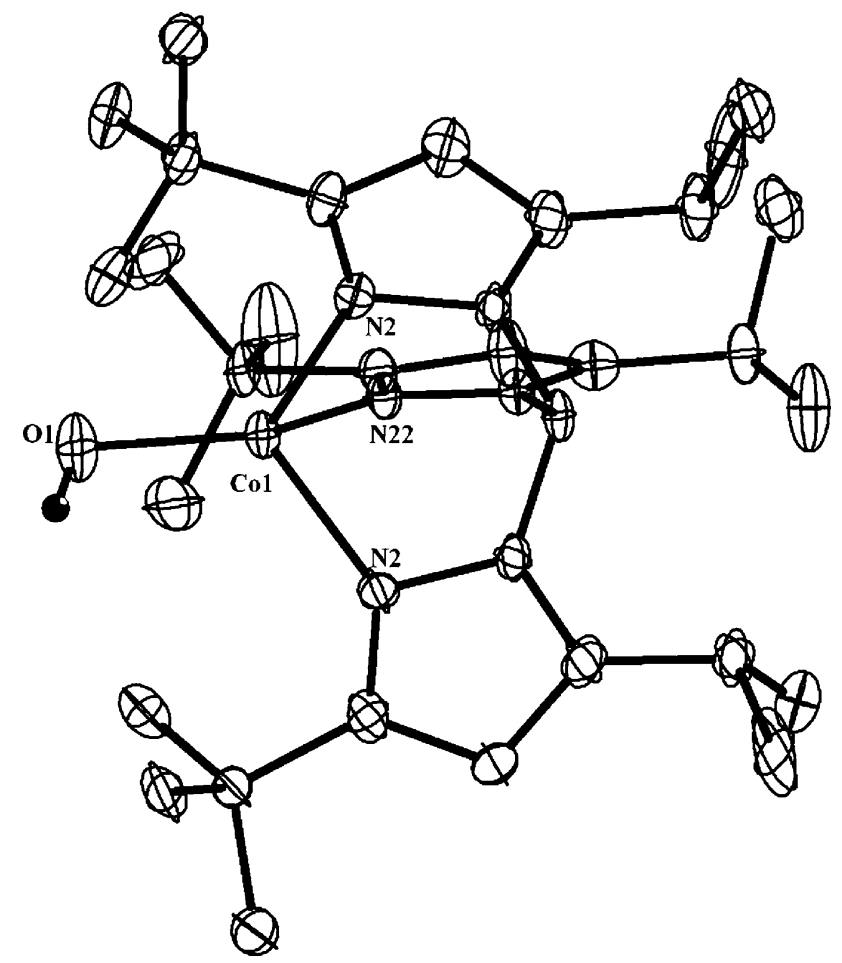

Fig. 3 Molecular structure of the $\mathrm{Co}\left\{\mathrm{HB}\left(3-{ }^{\mathrm{t}} \mathrm{Bu}-5-{ }^{\mathrm{i}} \mathrm{Prpz}\right)_{3}\right\}(\mathrm{OH}) 4$

[ $\mathrm{Zn}\left(\mathrm{HB}\left(3{ }^{-}{ }^{\mathrm{t}} \mathrm{Bu}-5-\mathrm{Mepz}\right)_{3}\right]_{2}\left(\mathrm{CO}_{3}\right)$ where each zinc center is four coordinate $[33,34]$. In $\left[\mathrm{Co}\left(\mathrm{HB}\left(3,5{ }^{\mathrm{i}} \mathrm{Pr}_{2} \mathrm{pz}\right)_{3}\right]_{2}\left(\mathrm{CO}_{3}\right)\right.$ complex the coordination mode of $\mathrm{CO}_{3}$ is completely different from that of $\mathbf{5}$ as in this complex, the carbonate group is coordinated to both cobalt ions in bidentate fashion. Accordingly, one of the $\mathrm{Co}-\mathrm{O} 1$ bonds, where $\mathrm{O} 1$ denotes the oxygen atom of the carbonate group sitting between the two cobalt centers, is more elongated (ca. $2.27 \AA$ ) than the other (ca. $2.06 \AA$ ) and the bond distances between the cobalt and carbonato oxygens (O2 or O3) which are terminally bound to one side cobalt ion and are not equal: Co1-O2 (2.09 $\AA$ ) vs Co2-O3 (1.99 $\AA$ ). This is nice example of asymmetrical $\eta_{1} \eta_{2}$ coordination mode of a 
Fig. 4 Molecular structure of $\left[\mathrm{Co}\left\{\mathrm{HB}\left(3-{ }^{\mathrm{t}} \mathrm{Bu}-\right.\right.\right.$

5- $\left.\left.\left.{ }^{\mathrm{i}} \mathrm{Prpz}\right)_{3}\right\}\right]_{2}(\mathrm{CO} 3) 5$

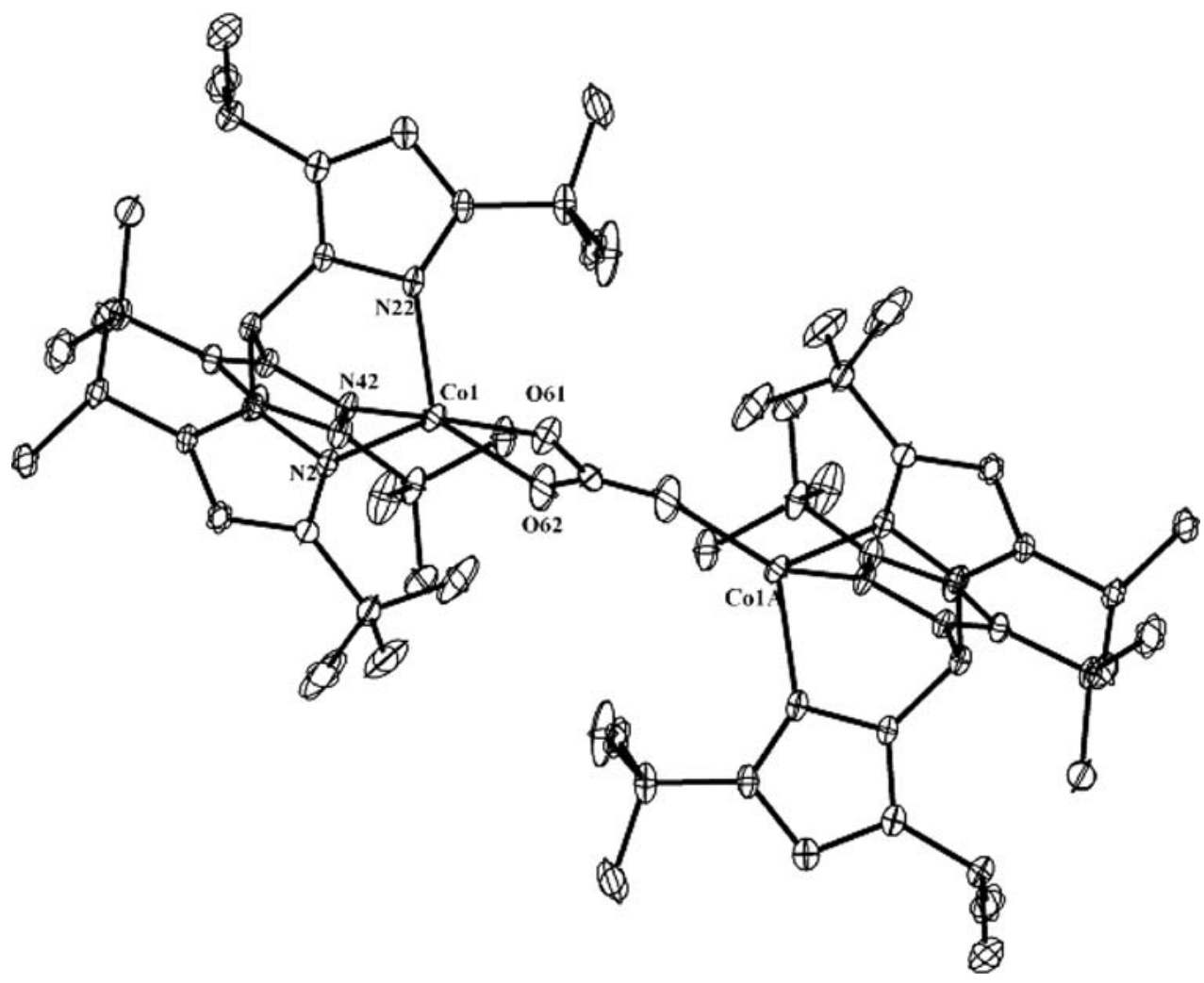

carbonate group in a binuclear cobalt complex. The steric hindrance on Tp ligands as well as the nature of hydroxo (binuclear or mononuclear) complex seems to play an important role in deciding the coordination mode of $\mathrm{CO}_{2}$ in its reaction product.

Molecular structure of $\left[\mathrm{Co}\left\{\mathrm{HB}\left(3-{ }^{t} \mathrm{Bu}-5-{ }^{i} \mathrm{Prpz}\right)_{3}\right\}\right.$ $\left.\left(\mathrm{OC}_{6} \mathrm{H}_{4}-4-\mathrm{NO}_{2}\right)\right]$ (6)

Complex $\mathbf{6}$ was prepared by reaction of $\mathbf{4}$ and 4-nitrophenylacetate in 2:1 ratio in $\mathrm{CH}_{2} \mathrm{Cl}_{2} / \mathrm{CH}_{3} \mathrm{CN}$ for $5 \mathrm{~h}$ (Scheme 2). Single crystals suitable for $\mathrm{X}$-ray measurement were obtained by cooling of an acetonitrile solution to $-20{ }^{\circ} \mathrm{C}$. Important bond lengths and angles are given in Table 3. As shown in Fig. 5, the cobalt atom is in pseudotetrahedral environment and is coordinated by the tridentate pyrazolylborate ligand and a monodentate 4-nitrophenolate anion. The Co1-O61 bond distance is

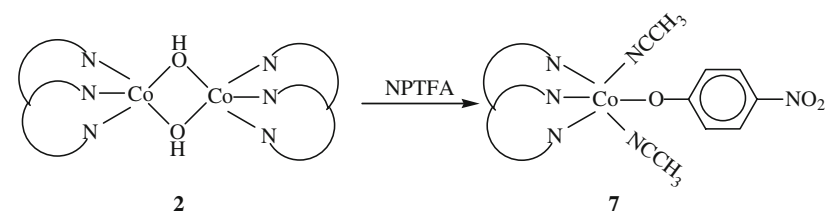

Scheme 3 Synthesis of complex 7
$1.890(5) \AA$ which is slightly longer than the $\mathrm{Zn}-\mathrm{O}$ bond distance (1.860 (2) $\AA$ ) in reported 4-nitrophenolate complex of zinc [35] and also than $\mathrm{Co}-\mathrm{O}$ bond length in complex 4. The Co-N bond distances in present complex are Co1-N42; 2.022 (6), Co2-N(2); 2.024 (5), and Co1$\mathrm{N} 22 ; 2.042$ (5) $\AA$ and are very similar to the $\mathrm{Zn}-\mathrm{N}$ bond distances (Zn-N1, 2.015(2); Zn-N2, 2.024(2); Zn-N3, 2.051(2) $\AA$ ) in zinc-nitrophenolate complex [35]. The Co1-O61-C62 bond angle $\left(151.3(3)^{\circ}\right)$ is larger than $\mathrm{Zn}-\mathrm{O}-\mathrm{C} 132.6(2)^{\circ}$ in zinc-nitrophenolate [35].

Molecular structure of $\left[\mathrm{Co}\left\{\mathrm{HB}\left(3,5-{ }^{i} \mathrm{Pr}_{2} \mathrm{pz}\right)_{3}\right\}\left(\mathrm{OC}_{6} \mathrm{H}_{4}-4-\right.\right.$ $\left.\left.\mathrm{NO}_{2}\right)\left(\mathrm{CH}_{3} \mathrm{CN}\right)_{2}\right](7)$

The reaction of $\mathbf{2}$ with 4-nitrophenyltrifluoroacetate (Scheme 3) resulted the formation of complex 7. The structure of $\mathbf{7}$ was determined by X-ray crystallography and is given in Fig. 6. The cobalt(II) atom is octahedrally coordinated by the tripodal anionic pyrazolylborate ligand, a 4-nitrophenolate anion and two acetonitrile ligands bound in a cisoid fashion. The cobalt-nitrogen bond distances from the tris(pyrazolyl)borate ligand are (Co1-N1, 2.147(4); Co1-N3, 2.140(4); Co1-N5, 2.144(5) ̊, which is longer than the $\mathrm{Co}-\mathrm{N}$ bond distances in four coordinated cobalt-nitrophenolate complex having $\mathrm{HB}\left(3{ }^{-}{ }^{\mathrm{t}} \mathrm{Bu}-5{ }^{\mathrm{i}} \mathrm{Prpz}\right)_{3}$ ligand. The $\mathrm{Co}-\mathrm{O}$ bond distance (Co1-O1, 2.016(4) $\AA$ ) which is again greater than $\mathrm{Co}-\mathrm{O}$ bond distance $(\mathrm{Co} 1-\mathrm{O} 1$, 
Table 3 Selected bond distances $(\AA)$ and bond angles $\left({ }^{\circ}\right)$ for $\left[\mathrm{Co}\left\{\mathrm{HB}\left(3-{ }^{\mathrm{t}} \mathrm{Bu}-5-{ }^{\mathrm{i}} \mathrm{Prpz}\right)_{3}\right\}(\mathrm{OH})\right](4),\left[\mathrm{Co}\left\{\mathrm{HB}\left(3-{ }^{\mathrm{t}} \mathrm{Bu}-5-{ }^{\mathrm{i}} \mathrm{Prpz}\right)_{3}\right]_{2}\left(\mathrm{CO}_{3}\right)\right.$ (5 - $\left.3 \mathrm{CH}_{2} \mathrm{Cl}_{2} \cdot \mathrm{CH}_{3} \mathrm{CN}\right), \quad\left[\mathrm{Co}\left\{\mathrm{HB}\left(3-{ }^{\mathrm{t}} \mathrm{Bu}-5-{ }^{\mathrm{i}} \mathrm{Prpz}\right)_{3}\right\}\left(\mathrm{OC}_{6} \mathrm{H}_{4}-4 \mathrm{NO}_{2}\right)\right]$ (6. $\left.2 \mathrm{CH}_{3} \mathrm{CN}\right), \quad\left[\mathrm{Co}\left\{\mathrm{HB}\left(3,5-{ }^{\mathrm{i}} \mathrm{Prpz}\right)_{3}\right\}\left(\mathrm{OC}_{6} \mathrm{H}_{4}-4 \mathrm{NO}_{2}\right)\left(\mathrm{CH}_{3} \mathrm{CN}\right)_{2}\right]$ $\left(7 \cdot 4 \mathrm{CH}_{3} \mathrm{CN}\right)$

$\left[\mathrm{Co}\left\{\mathrm{HB}\left(3-{ }^{\mathrm{t}} \mathrm{Bu}-5-{ }^{\mathrm{i}} \mathrm{Prpz}\right)_{3}\right\}(\mathrm{OH})\right](4)$

$\begin{array}{llll}\mathrm{Co}(1)-\mathrm{O}(1) & 1.854(3) & \mathrm{O}(1)-\mathrm{Co}(1)-\mathrm{N}(22) & 123.8(2) \\ \mathrm{Co}(1)-\mathrm{N}(2) \# 1 & 2.042(3) & \mathrm{O}(1)-\mathrm{Co}(1)-\mathrm{N}(2) \# 1 & 121.95(10) \\ \mathrm{Co}(1)-\mathrm{N}(22) & 2.031(3) & \mathrm{N}(22)-\mathrm{Co}(1)-\mathrm{N}(2) \# 1 & 93.50(10) \\ \mathrm{Co}(1)-\mathrm{N}(2) & 2.042(3) & \mathrm{O}(1)-\mathrm{Co}(1)-\mathrm{N}(2) & 121.95(10) \\ & & \mathrm{N}(22)-\mathrm{Co}(1)-\mathrm{N}(2) & 93.50(10) \\ & & \mathrm{N}(2) \# 1-\mathrm{Co}(1)-\mathrm{N}(2) & 94.24(14)\end{array}$

$\left[\mathrm{Co}\left\{\mathrm{HB}\left(3-{ }^{\mathrm{t}} \mathrm{Bu}-5-{ }^{\mathrm{i}} \mathrm{Prpz}\right)_{3}\right]_{2}\left(\mathrm{CO}_{3}\right)\left(\mathbf{5} \cdot 3 \mathrm{CH}_{2} \mathrm{Cl}_{2} \cdot \mathrm{CH}_{3} \mathrm{CN}\right)\right.$

$\begin{array}{llll}\mathrm{Co}(1)-\mathrm{O}(62) & 1.970(3) & \mathrm{O}(62)-\mathrm{Co}(1)-\mathrm{N}(2) & 125.63(11) \\ \mathrm{Co}(1)-\mathrm{N}(22) & 2.078(2) & \mathrm{N}(2)-\mathrm{Co}(1)-\mathrm{N}(22) & 95.42(9) \\ \mathrm{Co}(1)-\mathrm{O}(61) & 2.151(4) & \mathrm{O}(62)-\mathrm{Co}(1)-\mathrm{N}(22) & 131.98(11) \\ \mathrm{Co}(1)-\mathrm{N}(2) & 2.075(2) & \mathrm{O}(62)-\mathrm{Co}(1)-\mathrm{N}(42) & 111.04(12) \\ \mathrm{Co}(1)-\mathrm{N}(42) & 2.078(2) & \mathrm{N}(2)-\mathrm{Co}(1)-\mathrm{N}(42) & 90.24(9) \\ & & \mathrm{N}(22)-\mathrm{Co}(1)-\mathrm{N}(42) & 90.11(9) \\ & & \mathrm{O}(62)-\mathrm{Co}(1)-\mathrm{O}(61) & 56.29(15) \\ & & \mathrm{N}(2)-\mathrm{Co}(1)-\mathrm{O}(61) & 100.93(14) \\ & & \mathrm{N}(22)-\mathrm{Co}(1)-\mathrm{O}(61) & 96.11(14) \\ & & \mathrm{N}(42)-\mathrm{Co}(1)-\mathrm{O}(61) & 166.60(13)\end{array}$

$\left[\mathrm{Co}\left\{\mathrm{HB}\left(3-{ }^{\mathrm{t}} \mathrm{Bu}-5-{ }^{\mathrm{i}} \mathrm{Prpz}\right)_{3}\right\}\left(\mathrm{OC}_{6} \mathrm{H}_{4}-4 \mathrm{NO}_{2}\right)\right]\left(\mathbf{6} \cdot 2 \mathrm{CH}_{3} \mathrm{CN}\right)$

\begin{tabular}{llll}
$\mathrm{Co}(1)-\mathrm{O}(61)$ & $1.884(4)$ & $\mathrm{O}(61)-\mathrm{Co}(1)-\mathrm{N}(42)$ & $134.00(17)$ \\
$\mathrm{Co}(1)-\mathrm{N}(2)$ & $2.026(4)$ & $\mathrm{O}(61)-\mathrm{Co}(1)-\mathrm{N}(2)$ & $117.70(17)$ \\
$\mathrm{Co}(1)-\mathrm{N}(42)$ & $2.025(4)$ & $\mathrm{N}(42)-\mathrm{Co}(1)-\mathrm{N}(2)$ & $95.93(16)$ \\
$\mathrm{Co}(1)-\mathrm{N}(22)$ & $2.041(4)$ & $\mathrm{O}(61)-\mathrm{Co}(1)-\mathrm{N}(22)$ & $112.37(15)$ \\
& & $\mathrm{N}(42)-\mathrm{Co}(1)-\mathrm{N}(22)$ & $93.54(16)$ \\
& & $\mathrm{N}(2)-\mathrm{Co}(1)-\mathrm{N}(22)$ & $94.86(15)$ \\
{$\left[\mathrm{Co}\left\{\mathrm{HB}\left(3,5-{ }_{-}{ }^{\mathrm{Prpz}}\right)_{3}\right\}\left(\mathrm{OC}_{6} \mathrm{H}_{4}-4 \mathrm{NO}_{2}\right)\left(\mathrm{CH}_{3} \mathrm{CN}\right)_{2}\right]\left(7 \cdot 4 \mathrm{CH}_{3} \mathrm{CN}\right)$} \\
$\mathrm{Co}(1)-\mathrm{O}(1)$ & $2.016(4)$ & $\mathrm{O}(1)-\mathrm{Co}(1)-\mathrm{N}(3)$ & $89.19(16)$ \\
$\mathrm{Co}(1)-\mathrm{N}(5)$ & $2.144(5)$ & $\mathrm{O}(1)-\mathrm{Co}(1)-\mathrm{N}(5)$ & $176.45(17)$ \\
$\mathrm{Co}(1)-\mathrm{N}(8)$ & $2.181(4)$ & $\mathrm{N}(3)-\mathrm{Co}(1)-\mathrm{N}(5)$ & $87.81(16)$ \\
$\mathrm{Co}(1)-\mathrm{N}(3)$ & $2.140(4)$ & $\mathrm{O}(1)-\mathrm{Co}(1)-\mathrm{N}(1)$ & $91.85(16)$ \\
$\mathrm{Co}(1)-\mathrm{N}(1)$ & $2.147(4)$ & $\mathrm{N}(3)-\mathrm{Co}(1)-\mathrm{N}(1)$ & $87.11(17)$ \\
$\mathrm{Co}(1)-\mathrm{N}(7)$ & $2.203(5)$ & $\mathrm{N}(5)-\mathrm{Co}(1)-\mathrm{N}(1)$ & $86.09(16)$ \\
& & $\mathrm{O}(1)-\mathrm{Co}(1)-\mathrm{N}(8)$ & $89.11(16)$ \\
& & $\mathrm{N}(3)-\mathrm{Co}(1)-\mathrm{N}(8)$ & $177.5(2)$ \\
& & $\mathrm{N}(5)-\mathrm{Co}(1)-\mathrm{N}(8)$ & $93.95(17)$ \\
& & $\mathrm{N}(1)-\mathrm{Co}(1)-\mathrm{N}(8)$ & $94.79(18)$ \\
& & $\mathrm{N}(3)-\mathrm{Co}(1)-\mathrm{N}(7)$ & $90.81(17)$ \\
& & $\mathrm{N}(1)-\mathrm{Co}(1)-\mathrm{N}(7)$ & $175.16(18)$ \\
& & $\mathrm{N}(5)-\mathrm{Co}(1)-\mathrm{N}(7)$ & $89.47(15)$ \\
& & $\mathrm{O}(1)-\mathrm{Co}(1)-\mathrm{N}(7)$ & $92.49(16)$ \\
& & $\mathrm{N}(8)-\mathrm{Co}(1)-\mathrm{N}(7)$ & $87.41(18)$ \\
\hline & &
\end{tabular}

1.884(4) $\AA$ ) in 6 and $\mathrm{Zn}-\mathrm{O}$ bond distance $(1.860$ (2) $\AA$ ) in 4-nitrophenolate complex of zinc [35]. The Co1-O1-C28, bond angle is $139.0(3)^{\circ}$ which is smaller than the Co1O61-C62 bond angle $\left(151.3(3)^{\circ}\right)$ in $\mathrm{HB}\left(3-{ }^{\mathrm{t}} \mathrm{Bu}-5-{ }^{\mathrm{i}} \mathrm{Prpz}\right)_{3}$ bonded cobalt-nitrophenolate complex but larger than $\mathrm{Zn}-$ $\mathrm{O}-\mathrm{C}\left(132.6(2)^{\circ}\right)$ in zinc-nitrophenolate [35].

Infrared spectra and magnetic properties of complexes

The IR spectrum of complex 3 shows two bands at 1,528 and $1,275 \mathrm{~cm}^{-1}$ due to asymmetric and symmetric nitrate stretching. The presence of $v(\mathrm{OH})$ band at $3,670 \mathrm{~cm}^{-1}$ in 4 suggested the coordination of hydroxo group which was confirmed in X-ray structure. Complex 5 exhibits a pronounced $\mathrm{CO}$ vibration at $1,604 \mathrm{~cm}^{-1}$ indicating the possibility of $\mathrm{CO}_{3}{ }^{2-}$ coordination to the metal center. In the IR spectrum of complexes $\mathbf{6}$ and 7, the bands due to $v(\mathrm{~N}=\mathrm{O})$ appeared at 1,583 and $1,312 \mathrm{~cm}^{-1}$ indicating the coordination of $p$-nitrophenolate as monodentate. The coordination of acetonitrile to the cobalt atom in $\mathbf{7}$ is supported by the presence of $v(\mathrm{CN})$ at $2,279 \mathrm{~cm}^{-1}$. The temperature-dependent magnetic susceptibility measurement of complex 5 shows very weak antiferromagnetic coupling which is less than $2 \mathrm{~cm}^{-1}$, and the magnetic moment of about 6.00 B.M. between 150 and $300 \mathrm{~K}$ is very similar to the magnetic behavior of other cobalt complexes $[36,37]$. The fit and the dependence of the effective magnetic moment on temperature are displayed in Fig. S-1 of the supporting materials. The room temperature magnetic moment of $\mathbf{3}$ and $\mathbf{4}$ are 3.70 and 4.48 B.M., respectively.

\section{Conclusions}

In conclusion, we have reported the crystal structure of a mononuclear cobalt(II) hydroxo complex which is reactive toward $\mathrm{CO}_{2}$ and esters. In general, a metal-bound hydroxo species is regarded as a nucleophile. The nucleophilicity of the hydroxo moiety in complexes $\mathbf{2}$ and $\mathbf{4}$ was investigated by kinetic experiments of 4-nitrophenylacetate hydrolysis along with other carboxylate and phosphate esters. The kinetic experiments indicated that the rate of generation of 4-nitrophenolate ion was varied from ester to ester and $\mathrm{TpCoOH}$ is the kinetically active species. The hydrolysis of ester occurs via a binuclear mechanism involving the nucleophilic attack of the metal-bound hydroxide to the carbonyl group of the ester as reported by other workers also [38-44]. The carbonic anhydrase also promotes the hydrolysis of 4-nitrophenylacetate [45] and follows second order kinetics, involving the direct nucleophilic attack at the carbonyl group by a $\mathrm{Zn}-\mathrm{OH}$ species or hydroxo of other substituted metal ions. In order to get the model compound for $\mathrm{CA}$, we also performed the reaction of complex 4 with $\mathrm{CO}_{2}$, but due to poor solubility, the crystallized product was carbonato bridged $\mathbf{5}$ in place of mononuclear hydrogen carbonato complex. 
Fig. 5 Molecular structure of $\mathrm{Co}\left\{\mathrm{HB}\left(3-{ }^{\mathrm{t}} \mathrm{Bu}-\right.\right.$

5- $\left.\left.{ }^{\mathrm{i}} \mathrm{Prpz}\right)_{3}\right\}\left(\mathrm{OC}_{6} \mathrm{H}_{4}-\mathrm{p}-\mathrm{NO}_{2}\right) 6$

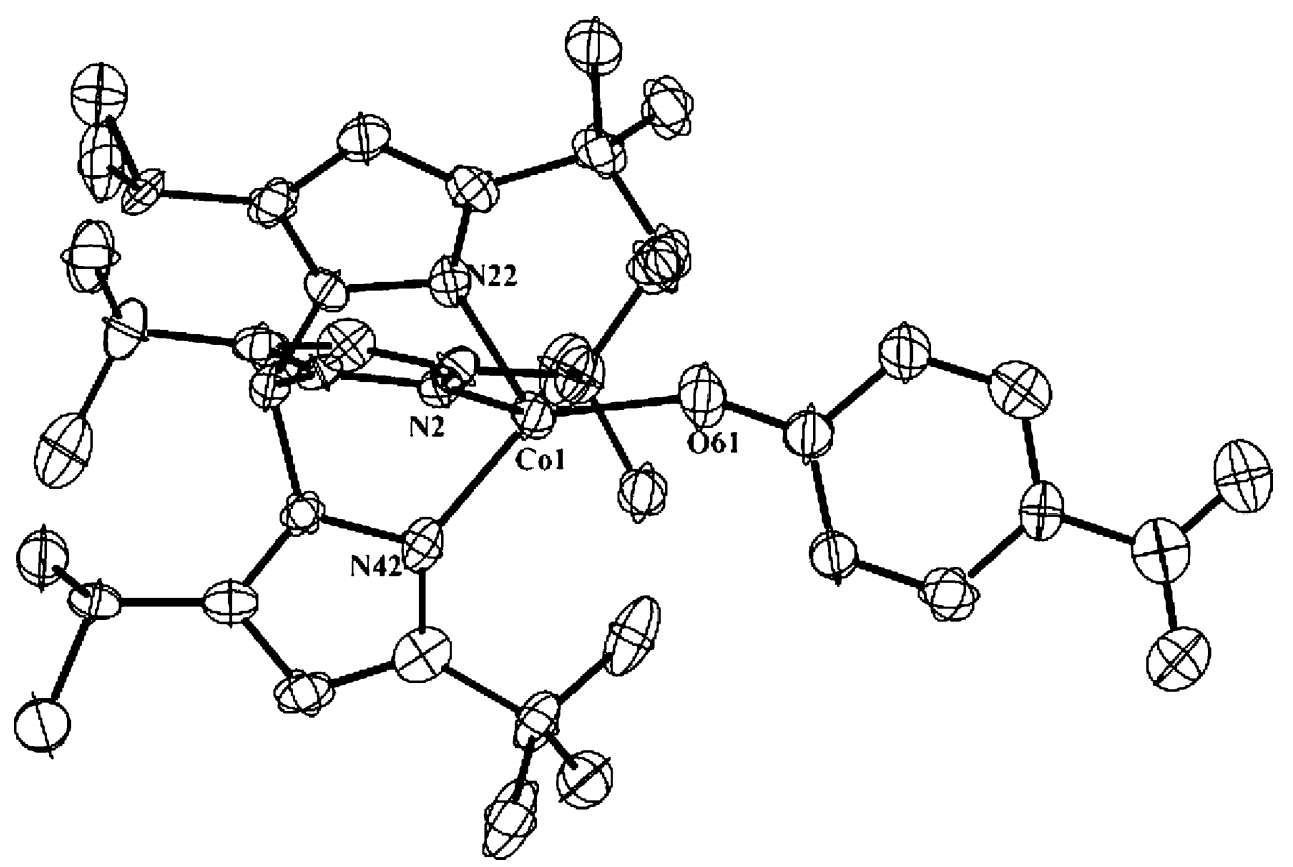

Fig. 6 Molecular structure of $\mathrm{Co}\left\{\mathrm{HB}\left(3,5-{ }^{\mathrm{i}} \mathrm{Prpz}\right)_{3}\right\}\left(\mathrm{OC}_{6} \mathrm{H}_{4}-\mathrm{p}-\right.$ $\left.\mathrm{NO}_{2}\right)\left(\mathrm{CH}_{3} \mathrm{CN}\right)_{2} 7$

\section{Supplementary material}

CCDC numbers 659652-659655 contain the supplementary crystallographic data (CIF) for this article. These data can be obtained free of charge from the Director, CCDC, 12 Union Road, Cambridge CB2 1EZ, UK (Fax: +44-1223336-033; e-mail: deposit@ccdc.cam.ac.uk).

Acknowledgments The authors are thankful to CSIR and AICTE, New Delhi, for the financial support in the form of research projects. UPS is grateful to the Alexander von Humbold Foundation for

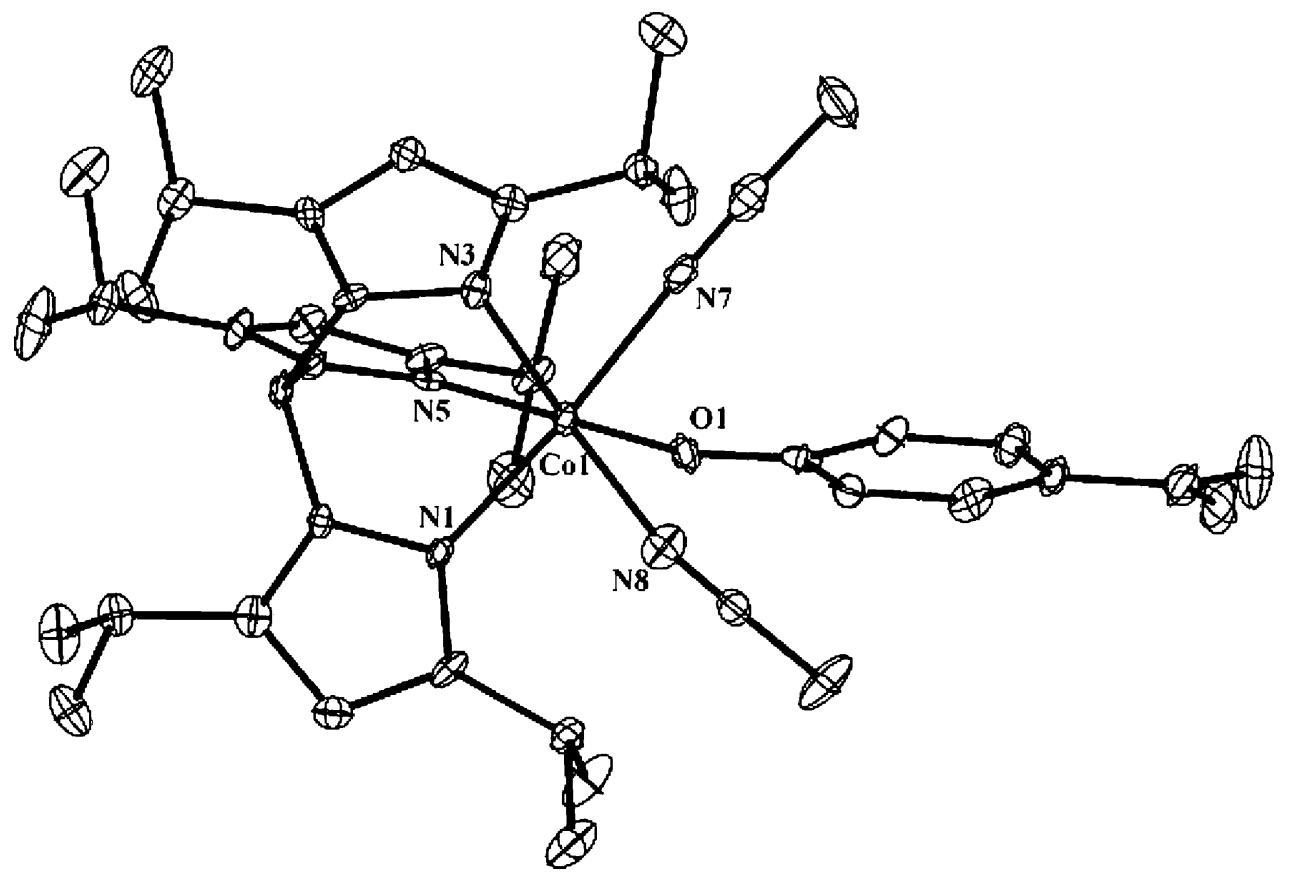

supporting the visit to Max-Planck-Institute für Bioanorganische Chemie, Mülheim, Germany, and Prof. K. Wieghardt for providing laboratory space and also for his continuous encouragement during my stay.

\section{References}

1. Vallee BL, Auld DS (1993) Acc Chem Res 26:543. doi: 10.1021/ar00034a005

2. Lipscome WN, Strater N (1996) Chem Rev 96:2396 
3. Canary JW, Xu J, Castagnetto JM, Rentzeperis D, Marky LA (1995) J Am Chem Soc 117:11545. doi:10.1021/ja00151a019

4. Lindskog S, Ibrahim SA, Jonsson BH, Simonsson I (1983) In: Bertini I, Drago RS, Luchinat C (eds) The coordination chemistry of Metalloenzymes. Springer

5. Wilcox DE (1996) Chem Rev 96:2435. doi:10.1021/cr950043b

6. Steinhagen H, Helmchem G (1996) Angew Chem Int Ed Engl 35:2339. doi:10.1002/anie.199623391

7. Holz RC (2002) Coord Chem Rev 5:232

8. Humphry T, Forconi M, Williams NH, Hengge AC (2004) J Am Chem Soc 126:11864. doi:10.1021/ja047110g

9. Seo JS, Hynes RC, Williams D, Chin J, Sung ND (1998) J Am Chem Soc 120:9943. doi:10.1021/ja9811905

10. Atkinson IM, Lindoy LF (2000) Coord Chem Rev 200-202:207. doi:10.1016/S0010-8545(00)00255-1

11. Jones DR, Lindoy LF, Sargeson AM (1983) J Am Chem Soc 105:7327. doi:10.1021/ja00363a021

12. Brown RS, Curtis NJ, Kusuma S, Salmon D (1982) J Am Chem Soc 104:3188. doi:10.1021/ja00375a043

13. Gellmann SH, Petter R, Breslow R (1986) J Am Chem Soc 108:2388. doi:10.1021/ja00269a041

14. Kimura E, Shiota T, Koike T, Shiro M, Kodama M (1990) J Am Chem Soc 112:5805. doi:10.1021/ja00171a020

15. Alsfasser R, Trofimenko S, Looney A, Parkin G, Vahrenkamp H (1991) Inorg Chem 30:4098. doi:10.1021/ic00021a026

16. Kitajima N, Hikichi S, Tanaka M, Moro-oka Y (1993) J Am Chem Soc 115:5496. doi:10.1021/ja00066a018

17. Hikichi S, Ogihara T, Fujisawa K, Kitajima N, Akita M, Morooka Y (1997) Inorg Chem 36:4539. doi:10.1021/ic960903m

18. Fujisawa K, Kobayashi T, Fujita K, Kitajima N, Mora-oka Y, Miyashita Y, Yamada Y, Okamoto K (2000) Bull Chem Soc Jpn 73:1797. doi:10.1246/bcsj.73.1797

19. Perrin DD, Armarego WL, Perrin DR (1980) Purification of laboratory chemicals, 2nd edn. Pergamon, New York

20. Imai S, Fujisawa K, Kobayashi T, Shirasawa N, Fujii H, Yoshimura T, Kitajima N, Moro-oka Y (1998) Inorg Chem 37:3066. doi:10.1021/ic970138r

21. Sheldrick GM (1990) Acta Cryst A46:467. doi:10.1107/ S0108767390000277

22. Sheldrick GM, SHELX TL-NT 2000 version 6.12, reference manual. University of Göttingen, Göttingen, Germany

23. Brown RS, Zamkanei M, Cocho JL (1984) J Am Chem Soc 106:5222. doi:10.1021/ja00330a031

24. Jairam R, Lau ML, Adornate J, Potvin PG (2001) J Inorg Biochem 84:113. doi:10.1016/S0162-0134(00)00210-5
25. Atkins PW (1996) The elements of physical chemistry. W. H. Freeman \& Co, New York

26. Gellman SH, Petter R, Breslow R (1989) J Am Chem Soc 108:2388. doi:10.1021/ja00269a041

27. Koike T, Kimura E (1991) J Am Chem Soc 113:8935. doi: 10.1021/ja00023a048

28. Koike T, Kajitani S, Nakamura I, Kimura E, Shiro M (1995) J Am Chem Soc 117:1210 and references their-in

29. Kimura E, Koike $T$ (1997) Adv Inorg Chem 44:229

30. Vallee BL (1986) In: Bertini I, Luchinat C, Maret W, Zeppezauer $\mathrm{Z}$ (eds) Zinc enzymes, Chap 1. Brikhauser, Boston, pp 1-15

31. Hikichi S, Komatasuzaki H, Akita M, Moro-oka Y (1998) J Am Chem Soc 120:4699. doi:10.1021/ja9720523

32. Bergquist C, Fillebeen T, Morlok MM, Parkin G (2003) J Am Chem Soc 125:6189 10.1021/ja034711j

33. Looney A, Parkin G, Alsfasser R, Ruf M, Vahrenkamp H (1992) Angew Chem Int Ed Engl 31:92. doi:10.1002/anie.199200921

34. Han R, Looney A, McNeill K, Parkin G, Rheingold AL, Haggerty BS (1993) J Inorg Biochem 49:105. doi:10.1016/0162-0134(93) 85020-9

35. Walz R, Weis K, Ruf M, Vahrenkamp H (1997) Chem Ber 130:975. doi:10.1002/cber.19971300727

36. Little IR, Straughan BP (1986) J Chem Soc Dalton Trans 2211. doi:10.1039/dt9860002211

37. Black D, Blake AJ, Dancey KP, Harrison A, McPartlin M, Parsons S, Tasker PA, Whittaker G, Schroder M (1998) J Chem Soc Dalton Trans 23:3953. doi:10.1039/a807031h

38. Koike T, Kimura E, Nakamura I, Hashimoto Y, Shiro M (1992) J Am Chem Soc 114:7338. doi:10.1021/ja00045a002

39. Kimura E (1992) Tetrahedron 30:6175. doi:10.1016/S0040-4020 (01)88212-0

40. Zhang X, van Eldik R, Koike T, Kimura E (1993) Inorg Chem 32:5749. doi:10.1021/ic00077a017

41. Kimura E, Nakamura I, Koike T, Shionoya M, Kodama Y, Ikeda T, Shiro M (1994) J Am Chem Soc 116:4764. doi:10.1021/ ja00090a024

42. Zhang $X$, van Eldik $R$ (1995) Inorg Chem 34:5606. doi: 10.1021/ic00126a034

43. Koike T, Kimura E, Kodama M, Shiro M (1995) J Am Chem Soc 117:8304. doi:10.1021/ja00109a004

44. Brandsch T, Schell FA, Weis K, Ruf M, Muller B, Vahrenkamp H (1997) Chem Ber 130:283. doi:10.1002/cber.19971300223

45. Pocker Y, Stone JT (1967) Biochemistry 6:668. doi:10.1021/ bi00855a005 